\title{
The Role of Splanchnic Vasoconstrictor in Decreasing Peripheral Vasodilatation to Reduce Ascites Formation of Liver Cirrhosis
}

\author{
Nurul Akbar*, Soemarno†, Sumedi Sumarsonoł, Laurentius Lesmana*, Unggul Budi Husodo*, Ali Sulaiman*, \\ H.M. Sjaifoellah Noer*
}

\begin{abstract}
Abstrak
Vasodilatasi perifer menyebabkan pengisian yang relatif kurang pada kompartimen vaskular sehingga mengaktifkan mekanisme kompensasi, yang menyebabkan retensi sodium dan asites. Sintetik analog somatostatin adalah vasokonstriktor, yang menurunkan aliran darah splangnik sehingga mengurangi vasodilatasi perifer. Peranan splangnik vasokonstriktor terhadap vasodilatasi perifer belum pernah diselidiki. Penelitian ini dilakukan untuk mengevaluasi apakah vasokonstriksi splangnik yang menurunkan vasodilatasi perifer akan mengakibatkan pengurangan pembentukan asites pada sirosis hati. Penelitian ini adalah prospektif, kontrol, secara random pada kasus sirosis hati dengan asites. Grup A terdiri dari 7 kasus diobati dengan spironolakton $2 \times 100$ mg sehari dan grup B terdiri dari 8 kasus yang diberikan spironolakton $100 \mathrm{mg}$ dua kali sehari dan $0,1 \mathrm{mg}$ sintetik analog somatostatin sehari sekali subkutan dan grup $C$ terdiri dari 9 kasus yang diberikan spironolakton $100 \mathrm{mg}$ dua kali sehari dan 0,1 sintetik analog somatostatin $3 x$ sehari sekali subkutan selama 7 hari. Pada permulaan dan akhir studi diperiksa berat badan, diuresis, uji biokimia, elektrolit darah dan aliran vena porta. Berat badan dan diuresis diukur setiap hari. Penurunan berat badan secara bermakna terjadi pada grup C dibandingkan dengan pada grup $B$ dan grup $A(p=0.006, p=0.523$, dan $p=0.079$, berturut-turut). Efek pada diuresis meningkat bermakna pada grup $C$ dibandingkan grup $B$ dan grup $A(p=0.028, p=0.339$, dan $p=0.063$, berturut-turut $)$. Tidak didapatkan perbedaan aliran darah vena porta, uji biokimia, dan elektrolit darah antara permulaan dan akhir penelitian pada ketiga grup. Penelitian ini membuktikan bahwa terdapat peranan vasodilatasi perifer dalam pembentukan asites.
\end{abstract}

\begin{abstract}
The peripheral vasodilatation causes relative underfilling of the vascular compartment, which lead to ascites formation. A synthetic analogue of somatostatin has been shown to reduce splanchnic blood flow. The role of splanchnic vasoconstrictor in reducing peripheral vasodilatation is not yet elucidated. The aims of the study is to asses the role of splanchnic vasoconstriction on peripheral vasodilatation to decrease ascites formation. This study was a prospective, controlled, randomized on liver cirrhosis cases with ascites. Group $A$ consisted of 7 cases were treated with spironolactone two times $100 \mathrm{mg}$ a day, Group B consisted of 10 cases were treated with spironolactone two times $100 \mathrm{mg}$ a day plus $0,1 \mathrm{mg}$ somatostatin synthetic analogue once a day and Group C consisted of 9 patients treated with spironolactone two times $100 \mathrm{mg}$ a day plus $0,1 \mathrm{mg}$ somatostatin synthetic analogue three times a day. At the entry of the study and at the end, body weight, diuresis, biochemical test, blood electrolytes and portal blood flow. were measured. The body weight and diuresis were measured every day. The decrease of body weight was significant among Group C compared to Group B and Group $A(p=0.006, p=0.523$, and $p=0.079$, respectively). The diuresis effect was increased significantly among Group C compared to Group $B$ and Group $A(p=0.028, p=0.339$, and $p=0.063$, respectively). There were no increased of portal blood flow. This study proved the role of peripheral vasodilatation in water retention and ascites formation in cirrhosis cases.
\end{abstract}

Keywords: splanchnic vasoconstrictor, peripheral vasodilatation, ascites, liver cirrhosis

\section{INTRODUCTION}

Ascites is a major complication of liver cirrhosis. Simplistically, ascites forms in severe chronic or acute

\footnotetext{
* Department of Internal Medicine, Faculty of Medicine, University of Indonesia, Jakarta, Indonesia

† Department of Internal Medicine, Sint Carolus Hospital, Jakarta, Indonesia

$\ddagger$ Department of Community Medicine, University of Indonesia, Faculty of Medicine, Jakarta, Indonesia
}

liver disease as a results of portal hypertension, baroreceptor activation, and neurohumorally mediated abnormalities in renal perfusion, with resulting sodium retention. The controversy hinges on the initial stimulus for fluid retention. Several theories regarding the initiation of sodium retention in cirrhosis have been suggested. The underfill hypothesis gave way to overfill hypothesis, which has been replaced by the peripheral vasodilatation theory. ${ }^{2}$ The initiating event, according to the peripheral vasodilatation theory, is splanchnic hyperemia and portal hypertension, which 
is produced by the splanchnic vasodilator that accumulate due to reduced hepatic clearance and portosystemic shunting. ${ }^{3}$ This causes relative underfilling of the vascular compartment, thereby activating compensatory mechanism which reduced renal blood flow and cause sodium retention. This hypothesis does not explain the observation of Levy and colleagues that sodium retention in experimental cirrhosis was unassociated with changes in cardiac output and peripheral vascular resistance. ${ }^{4}$ Clearly, further studies are required to confirm the validity of this hypothesis.

A synthetic analogue of somatostatin (Octreotide, Sandoz Co, Switzerland) has been shown to reduce splanchnic blood flow. The role of splanchnic vasoconstrictor in reducing peripheral vasodilatation is not yet elucidated. In this study we investigated the effects of a splanchnic vasoconstrictor (Octreotide) on peripheral vasodilatation to decrease ascites formation.

\section{METHODS}

The study was a randomized, prospective, controlled study. The naive patients with liver cirrhosis and ascites were randomly assigned into three groups to received either spironolactone in a dose of two times $100 \mathrm{mg}$ a day 9 (Group A), or spironolactone two times $100 \mathrm{mg}$ a day plus $0.1 \mathrm{mg}$ octreotide once a day given by subcutaneously (Group B), and spironolactone two times $100 \mathrm{mg}$ a day plus $0.1 \mathrm{mg}$ octreotide three times a day given by subcutaneously (Group C) for one week.

On admission and within one week during hospitalization, an examination was performed daily, with assessment of general condition and vital signs, measurement of abdominal girth, body weight, diuresis and adverse side effect. Ascites was quantified using the following system; 1+ : Detectable only by careful examination

$2+$ : Easily detected but of relatively small volume

$3+$ : Obvious ascites but not tense

$4+:$ Tense ascites

Liver function test and ultrasonography to assess blood portal flow was performed at base line and the end of the week. The diagnosis was confirmed by clinical findings and USG (model Toshiba SA 100-A, Toshiba Ltd, Tokyo, Japan). The reduce of ascites formation can be shown by decrease of body weight, decrease of ascites and increase of diuresis.

Comparison between patients groups and within groups on age, gender, reducing of body weight, in- creasing of diuresis, disturbances of liver function test, blood electrolytes portal blood flow, were made with analysis variance (ANOVA), paired samples-t test and Wilcoxon Matched-pairs Signed-ranks test were appropriate.

Patients with evidence of uncontrolled, clinically significant cardiovascular, pulmonary, renal, pancreatic, metabolic, neurological, endocrine or other system disease, hepatoma, previously entered the study and taking non-selective beta blocking agents during 48 hours before were excluded. Pregnant and lactating women were not included in this study. Patients were to be 18 years old or over and were required to give oral informed consent.

This study was approved by the Ethics Committee of the Department of Internal Medicine Faculty of Medicine University of Indonesia. Informed consent was obtained from participants in this study.

\section{RESULTS}

Twenty-seven patients were included in this study. Group A consisted 8 cases, Group B 10 cases and Group C 9 cases. There were 19 men and 8 women. Twenty-six out of 27 patients who entered the study completed it. One patient in Group A with suspected hepatoma was excluded from the study. The diagnosis of liver cirrhosis was confirmed by ultrasonography findings. Liver biopsy was not performed. Table 1 showed the patients characteristic when entered the study. All groups were similarly distributed with respect to gender and age.

Table 1. Characteristic of subjects on entry of the study

\begin{tabular}{lllll}
\hline & Group A & Group B & Group C & p \\
\hline Number of cases & 7 & 10 & 9 & NS \\
Sex & & & & \\
$\quad$ Male & 5 & 7 & 6 & NS \\
$\quad$ Female & 2 & 3 & 3 & \\
Age & & & & \\
$\quad$ Minimal & 17 & 26 & 36 & NS \\
$\quad$ Maximal & 60 & 68 & 76 & \\
$\quad$ Mean & 31.0 & 42.20 & 61.30 & \\
$\quad$ Standard deviation & 12.66 & 13.86 & 13.86 & \\
Etiology & 2 & 2 & 3 & \\
$\quad$ Hepatitis B & 2 & 2 & 2 & \\
Hepatitis C & 3 & 6 & 4 & \\
Hepatitis non-A-E & 3 & & & \\
\hline
\end{tabular}

NS: not significant

Group A: treated with spironolactone

Group B: treated with spironolactone and $0.1 \mathrm{mg}$ octreotide one time a day

Group C: treated with spironolactone and $0.1 \mathrm{mg}$ octreotide three times a day 
Decreasing of body weight which indicate the decrease of ascites formation among three groups was shown in Table 2. At the day 4 , the decrease of body weight among Group C compared to Group B and Group A were significant $(p=0.028$ compared to $p=0.339$, and $\mathrm{p}=0.063$ ). At the end of the study the decrease of body weight in all groups were noted.

Increasing diuresis among three groups was demonstrated in Table 3. The diuresis during the day 1 to the day 4 was significant increased alıung Group C compared to Group B and Group A ( $p=0.006$ compared to $\mathrm{p}=0.523$, and $\mathrm{p}=0.079$ ). This results clearly showed the effect of vasoconstriction agent on splanchnic vasodilatation to induce diuresis. After the day 4 , the ascites have already much reduced in group $\mathrm{C}$ and $\mathrm{B}$ as shown in Table 4. At that time the diuresis in groups $C$ was similar with other groups because the ascites formation was much decreased in group $C$ compared to other groups as shown in Table 4.

Table 2. The efficacy of splanchnic vasoconstrictor in reducing body weight in liver cirrhosis patients

\begin{tabular}{|c|c|c|c|c|c|c|c|c|c|}
\hline & \multicolumn{3}{|c|}{ Group A (7 cases) } & \multicolumn{3}{|c|}{ Group B (10 cases) } & \multicolumn{3}{|c|}{ Group C ( 9 cases) } \\
\hline & \multicolumn{3}{|c|}{ Body weight } & \multicolumn{3}{|c|}{ Body weight } & \multicolumn{3}{|c|}{ Body weight } \\
\hline & Mean & SD & $\mathbf{p}$ & Mean & SD & $\mathbf{p}$ & Mean & SD & $\mathbf{p}$ \\
\hline Day 1 & 55.4 & 8.05 & & 57.4 & 7.89 & & 62.6 & 4.87 & \\
\hline Day 3 & 54.51 & 8.23 & 0.161 & 56.7 & 7.56 & 0.066 & 61.1 & 4.96 & 0.001 \\
\hline Day 4 & 53.93 & 7.86 & 0.079 & 57.0 & 8.13 & 0.523 & 60.6 & 5.55 & 0.006 \\
\hline Day 5 & 53.43 & 8.11 & 0.025 & 55.5 & 8.55 & 0.009 & 59.6 & 5.62 & 0.006 \\
\hline Day 7 & 52.14 & 7.38 & 0.005 & 55.0 & 8.62 & 0.007 & 58.4 & 5.99 & 0.003 \\
\hline
\end{tabular}

* significant, paired samples t-test

Body weight in kilogram

Group A: treated with spironolactone

Group B: treated with spironolactone and $0.1 \mathrm{mg}$ octreotide one time a day

Group C: treated with spironolactone and $0.1 \mathrm{mg}$ octreotide three times a day

Table 3. The efficacy of splanchnic vasoconstrictor in increasing diuresis of patients with ascites due to liver cirrhosis

\begin{tabular}{llllccccccc}
\hline & \multicolumn{3}{c}{ Diuresis in Group A } & \multicolumn{3}{c}{ Diuresis in Group B } & \multicolumn{3}{c}{ Diuresis in Group C } \\
\hline & Mean & SD & p & Mean & SD & p & Mean & SD & P \\
Day 1 & 1078.6 & 496.66 & & 1444.0 & 859.0 & & 1091.1 & 596.4 & \\
Day 4 & 1521.4 & 550.6 & 0.063 & 1309.5 & 634.4 & 0.155 & 1922.2 & 857.4 & 0.032 \\
Day 7 & 1550.0 & 715.9 & 0.128 & 1263.0 & 258.45 & 0.260 & 1305.6 & 681.2 & 0.487 \\
\hline
\end{tabular}

* significant, using Wilcoxon Matched-pairs Signed-ranks Test

Diuresis was measured by centimeter cubic/day

Group A: treated with spironolactone

Group B: treated with spironolactone and $0.1 \mathrm{mg}$ octreotide one time a day

Group C: treated with spironolactone and $0.1 \mathrm{mg}$ octreotide three times a day

Table 4 . The efficacy of splanchnic vasoconstrictor to reduce ascites in liver cirrhosis cases

\begin{tabular}{|c|c|c|c|c|c|c|c|c|c|c|c|c|}
\hline \multirow[b]{2}{*}{$\begin{array}{l}\text { Degree } \\
\text { of ascites }\end{array}$} & \multicolumn{4}{|c|}{ Group A } & \multicolumn{4}{|c|}{ Group B } & \multicolumn{4}{|c|}{ Group C } \\
\hline & Day 1 & Day 3 & Day 4 & Day 7 & Day 1 & Day 3 & Day 4 & Day 7 & Day 1 & Day 3 & Day 4 & Day 7 \\
\hline $3+$ & $7(100)$ & $7(100)$ & $4(57)$ & 0 & $9(90)$ & $7(70)$ & $4(40)$ & $1(10)$ & $8(89)$ & $3(33)$ & 0 & 0 \\
\hline $2+$ & 0 & 0 & $3(43)$ & $6(86)$ & $1(10)$ & $3(30)$ & $6(60)$ & $3(30)$ & $1(11)$ & $6(67)$ & $9(100)$ & $1(11)$ \\
\hline $1+$ & 0 & 0 & 0 & $1(14)$ & 0 & 0 & 0 & $6(60)$ & 0 & 0 & 0 & $2(22)$ \\
\hline 0 & 0 & 0 & 0 & 0 & 0 & 0 & 0 & 0 & 0 & 0 & 0 & $6(67)$ \\
\hline
\end{tabular}

( ): \%

Group A: treated with spironolactone only

Group B: treated with spironolactone and $0.1 \mathrm{mg}$ octreotide one time a day

Group C: treated with spironolactone and $0.1 \mathrm{mg}$ octreotide three times a day 
There were no differences on biochemical tests, systemic blood-pressure and portal blood flow at the entry

and the end of the study between groups as shown in Table 5 and 6.

Table 5. The biochemical tests and blood electrolytes before and after treatment

\begin{tabular}{|c|c|c|c|c|c|c|c|c|c|c|c|c|}
\hline & \multicolumn{4}{|c|}{ Group A } & \multicolumn{4}{|c|}{ Group B } & \multicolumn{4}{|c|}{ Group C } \\
\hline & \multicolumn{2}{|c|}{ Day 1} & \multicolumn{2}{|c|}{ Day 7} & \multicolumn{2}{|c|}{ Day 1} & \multicolumn{2}{|c|}{ Day 7} & \multicolumn{2}{|c|}{ Day 1} & \multicolumn{2}{|c|}{ Day 7} \\
\hline & Mean & SD & Mean & SD & Mean & SD & Mean & SD & Mean & SD & Mean & SD \\
\hline Albumin (g/l) & 2.47 & 0.97 & 2.58 & 0.90 & 2.75 & 0.76 & 3.05 & 0.84 & 3.00 & 0.8 & 3.12 & 0.89 \\
\hline Globulin (g/l) & 3.87 & 1.07 & 4.27 & 1.47 & 3.98 & 0.88 & 4.18 & 0.97 & 3.62 & 1.29 & 4.02 & 1.25 \\
\hline AST (IU) & 42.4 & 16.4 & 52.29 & 14.9 & 46.8 & 41.55 & 38.5 & 20.56 & 62.5 & 53.53 & 82.33 & 57.11 \\
\hline ALT (IU) & 46.0 & 23.4 & 40.6 & 15.5 & 45.0 & 35.22 & 34.2 & 20.86 & 23 & 12.41 & 41 & 24.70 \\
\hline $\begin{array}{l}\text { Conjugated } \\
\text { bilirubin (mg/dl) }\end{array}$ & 1.94 & 1.96 & 2.44 & 3.32 & 1.79 & 2.16 & 1.50 & 1.63 & 1.85 & 1.08 & 2.73 & 1.34 \\
\hline $\begin{array}{l}\text { Unconjugated } \\
\text { bilirubin (mg/dl) }\end{array}$ & 2.19 & 3.27 & 2.83 & 2.83 & 4.76 & 2.08 & 1.01 & 0.98 & 1.75 & 0.64 & 1.78 & 0.48 \\
\hline Ureum (mg/dl) & 34.2 & 7.99 & 32.7 & 10.01 & 28.5 & 7.95 & 25.5 & 10.04 & 28.6 & 14.71 & 27.8 & 9.96 \\
\hline Creatinine (mg/dl) & 0.93 & 0.10 & 0.97 & 0.19 & 0.86 & 0.14 & 0.83 & 0.13 & 0.85 & 0.17 & 0.9 & 0.22 \\
\hline Natrium (mEq/l) & 139 & 9.03 & 133 & 4.58 & 135 & 6.43 & 135 & 5.80 & 135 & 4.56 & 135 & 3.51 \\
\hline Chloride (mEq/) & 84 & 34.61 & 82 & 37.34 & 97.6 & 7.31 & 97.7 & 10.0 & 96.6 & 2.30 & 97.8 & 3.27 \\
\hline Kalium (mEq/I) & 3.79 & 0.70 & 4.14 & 0.65 & 4.06 & 0.66 & 4.10 & 10.0 & 4.00 & 0.32 & 4.39 & 0.70 \\
\hline
\end{tabular}

Group A: treated with spironolactone only

Group B: treated with spironolactone and $0.1 \mathrm{mg}$ octreotide one time a day

Group C: treated with spironolactone and $0.1 \mathrm{mg}$ octreotide three times a day

Table 6. The effect of splanchnic vasoconstrictor on portal blood flow

\begin{tabular}{|c|c|c|c|c|c|c|c|c|c|c|c|c|}
\hline & \multicolumn{4}{|c|}{ Group A } & \multicolumn{4}{|c|}{ Group B } & \multicolumn{4}{|c|}{ Group C } \\
\hline & \multicolumn{2}{|c|}{ Day 1} & \multicolumn{2}{|c|}{ Day 7} & \multicolumn{2}{|c|}{ Day 1} & \multicolumn{2}{|c|}{ Day 7} & \multicolumn{2}{|c|}{ Day 1} & \multicolumn{2}{|c|}{ Day 7} \\
\hline & Mean & SD & Mean & SD & Mean & SD & Mean & SD & Mean & SD & Mean & SD \\
\hline Centripetal & 19.53 & 7.42 & 11.63 & 1.42 & 9.67 & 1.82 & 10.1 & 3.86 & 13.74 & 6.13 & 9.73 & 1.57 \\
\hline Centrifugal & 14.53 & 3.93 & 9.73 & 1.86 & 6.35 & 1.91 & 10 & 5.66 & 14.29 & 6.83 & 10.3 & 1.2 \\
\hline
\end{tabular}

Group B: treated with spironolactone and $0.1 \mathrm{mg}$ octreotide three times a day

Group C: treated with spironolactone and $0.1 \mathrm{mg}$ octreotide one time a day

\section{DISCUSSION}

Renal sodium and water retention and plasma volume expansion have been shown to lead ascites formation in experimental cirrhosis. The classical "underfilling" theory, ${ }^{6}$ states that the spillover of fluid into the peritoneal is primary in ascites formation, which causes hypovolemia and initiates secondary renal sodium and water retention. In contrast to this theory, it was found blood volume to be high in patients with cirrhosis. $^{7}$

The occurrence of primary renal sodium and water retention and plasma volume expansion prior to ascites formation favors the "overflow" hypothesis but the stimulation of the renin- angiotensin-aldosterone system, vasopressin release and sympathetic nervous system associated with cirrhosis is not in agreement with primary volume expansion. ${ }^{8}$ The intravascular hypervolemia suppresses renin, aldosterone, norepinephrin, vasopressin, and the ability to handle a salt load is not normal. If the vasodilatation is becoming worst, renal function will be deteriorated and hepatorenal syndrome will develop.

According to latest proposed theory which named as peripheral vasodilatation theory, the "underfilling" theory and the "overflow" hypothesis are correct and each is working at a difference stage. ${ }^{3}$ The formation of ascites is considered to be continuum involving both 
overfill (early) and underfill (late) mechanism. Careful observation of clinical course proposes that vascular overflow becomes vascular underfill.

As noted, patients with decompensated liver disease manifest a hyperdinamic circulation characterized by increased cardiac index and heart rate, as well as decreased systemic vascular resistance. ${ }^{3}$ Indeed, the peripheral vasodilatation theory postulates that peripheral vasodilatation and an early increase in vascular capacitance constitute cardinal events in the pathogenesis of ascites and hepatorenal syndrome. The hepatorenal syndrome in cirrhosis was defined as a syndrome that occurs in patients with advanced hepatic failure and portal hypertension characterized by impaired renal function and marked abnormalities in the arterial circulation and activity of the endogenous vaso active systems. ${ }^{9}$ In the kidney, there is marked vasoconstriction that impairs glomerular infiltration rate. In the extrarenal circulation there is predominance of arteriolar vasodilatation that results in arterial hypotension.

There has been renewed interest in the hemodynamic arrangement and attempts to improve renal function by countervailing this hyperdynamic state. ${ }^{10}$ Lenz and colleagues investigated the effects of infusion of ornipressin on renal and circulatory function. ${ }^{11}$ They demonstrated that ornipressin reversed the hyperdynamic state. Concomitanly, there is improvement in renal function as assessed by a more than $70 \%$ increase in creatinine clearance and a doubling in urine flow.

Our study showed that urine flow was significantly increased, body weight was decreased and ascites formation reduced after administration of a splanchnic vasoconstrictor. Our observation lend support to the concept that the peripheral vasodilatation of liver disease contributes importantly to ascites formation. Con- sequently, maneuvers that counter the peripheral vasodilatation may prove benefit in reducing ascites formation.

\section{REFERENCES}

1. Runyon BA. Ascites. In Diseases of the liver ed. Schiff L. JB Lippincott Company, Philadelphia $7^{\text {th }}$ ed $1993 ; 2: 990$ 1015.

2. Witte MH, Witte CL, Dumont AE. Progress in liver disease: physiological factors involved in the causation of cirrhotic ascites. Gastroenterol 1971;61:742-50.

3. Schrier RW, Arroyo V, Bernardi M, Epstein M, Heriksen JH, Rodes J. Peripheral arterial vasodilatation hypothesis: a proposal for the initiation of renal sodium and water retention in cirrhosis. Hepatol 1988;8:1151-7.

4. Levy M, Allotey JB. Temporal relationship between urinary salt retention and altered systemic hemodynamics in dogs with experimental cirrhosis. J Lab Clin Med 1978;92:560.

5. Pringle SD, McKee RF, Garden OJ et al. The effect of a longacting somatostatin analogue on portal and systemic haemodynamics in cirrhosis. Alim Pharmacol Ther 1988;2:451-9.

6. Sherlock S, Shaldon S. The aetiology and management of ascites in patients with hepatic cirrhosis. A review: Gut 4:95, 1963.

7. Lieberman FL, Reynolds TB. Plasma volume in cirrhosis of the liver: its relation to portal hypertension, ascites, and renal failure, J Clin Invest 46:1297, 1967.

8. Lieberman FL, Denison EK, Reynolds TB. The relationship of plasma volume, portal hypertension, ascites, and renal sodium retension in cirrhosis: the overflow theory of ascites formation. Ann NY Acad Sci 70:202,1970.

9. Arroyo V, Fernandez-Esparrach G, Gines P. Diagnostic approach to the cirrhotic patient with ascites. J Hepatol 1996;25 (Suppl.1):35-40.

10. Moller S, Becker U, Schifter S, Abrahamsen J and Henriksen JH. Effect of oxygen inhalation on systemic, central, and splanchnic haemodynamics in cirrhosis. J Hepatology 1996; Volume 25 - issue 3.

11. Lenz K, Hortnagl H, Druml W, et al. Beneficial effect of 8 ornithine vasopressin on renal dysfunction in decompesated cirrhosis. Gut 1989;30:90. 